\title{
The Form of the Government Intervention for the Female Workers of the Informal Sector in Palembang City
}

\author{
Mirna Taufik \\ Monanisa \\ Armansyah \\ Lecturers of the Demographic Science \\ Geographic Education \\ Study Program \\ PGRI University of Palembang \\ South Sumatra, Indonesia \\ Nengyanti \\ Bambang Bemby Soebyakto \\ Lecturers \\ Post Graduate Program of Demographic Study Program \\ Sriwijaya University \\ Palembang, South Sumatra, Indonesia
}

\begin{abstract}
The objective of this study is to disclose the forms of government interventions that the female workers in the informal sector have experienced in Palembang City. The method used is the quantitative method withthe design of survey method. The data collected by means of questionnaires were analyzed by using the descriptive statistics and presented using descriptions and pie charts. The results of the study revealed that the government intervention were in the forms of providing skills, training, business capital, supervision, and information. Eventhough the percentage was still very low, the government intervention should be appreciated as motivation provider to the female workers in the informal sector, so that they can develop their business to get a decent income. In addition, this form of intervention can serve as a silencer for the accusation stating that so far the informal sector has been marginalized and has not been touched by government interference.
\end{abstract}

Keywords: intervention, women, informal sector

\section{Introduction}

Women are part of the Indonesian workforce, whose existence is now being taken into account. The gender mainstreaming program (GMP) has opened the way for Indonesian Kartini to work more broadly. GMP has been able to change the role of women not only limited to being housewives but also being workers at the same time (Ahdiah, 2013). Educated women can even occupy higher positions than those of men in the economic and political fields. In the field of employment, women's participation is increasingly high, BPS noted that the female labor force participation rate $(T P A K)$ for the period of August 2016 was 50.77 percent and in August 2017 it raised up to 50.89 percent. This meant that there was an increase of 0.12 percent of female TPAK (BPS, 2017).

The involvement of women in the world of employment will certainly have obstacles, especially for women who are married. The obligation to take care of the household, looking after the child, and serving the husband is still a basic task for Indonesian women. There are still some parents and husbands who forbid girls or wives to work. The reasons are shame, taboo (famali), and the assumption that the task of earning a living is the duty of a husband. However, there are also many modern-minded parents and husbands who allow their daughters or wives to work. They consider women who work as a form of self-actualization and the opportunity to work should be used as far as it is still within normal limits.

Even though they have been granted permission to work by their parents and husband, female workers will usually still fulfill their obligations as children to their parents and also as wives to their husbands. They will position themselves as women who have multiple roles (Aswiyati, 2016), namely as workers and housewives. The instinct of a woman who has a status as a mother will always lead her to prioritize the needs of her children over the priority of their work. 
Therefore, most female workers choose the type of work of informal nature that has a lot of free time. Because, working to female workers, is just a side activity, so it would be better if their work has a flexible time so it will be easy to manage the time between working and taking care of the household (Soebyakto \& Armansyah, 2016).

The current digital era allows women to work more flexibly both in terms of place and time. Women in the informal sector can use the internet as a medium to run a business. Unfortunately, due to limited education, skills and capital, women in the informal sector have difficulty using the media. This condition requires serious attention from the government, the government must review the existence of women in the informal sector. Considering the fact that competition is increasingly more complex in the world of employment, will it be rational to make female workers in the informal sector as one road map to start a business and then formalize their business?

It is not impossible for the female workers in the informal sector to become embryos for the formal sector. This can be done by treating the activities of women in the informal sector as a base for beginner entrepreneurs. This strategy seems to give hope to job seekers while the formal employment field is limited. The government can carry out a program of "empowerment of informal sector", which is a program that aims to foster female workers in the informal sector intensively within a program. The hope is that with the empowerment, women in the informal sector can earn a decent income, or even be able to recruit workers in the businesses they run, at least opening employment opportunities for the population in their neighborhood.

This hope can be realized if the government wants to be more responsive and care for women in the informal sector. The government must carry out various interventions for female workers in the informal sector with the aim of empowering the informal sector. From some existing literature, the forms of government intervention for the workers in the informal sector have been carried out such as; managing street vendors ( $P K L)$, providing access to banks (Ritonga \& Sari, 2015), establishing associations and cooperatives, involving informal sector workers in several parts of the formal sector work (Maryam Masood and Claire Y Barlow, 2013) and (Aparcana, 2017), providing health insurance and work safety services (Ramdan, 2012), providing low-cost housing and others.

Therefore, this study aims to explore the forms of intervention carried out by the Palembang City government for female workers in the informal sector. The city of Palembang was chosen as the research location due to its status as the capital of the South Sumatra Province. The city of Palembang is the center of population agglomeration as well as various economic activities. Therefore, it is possible to see the development of a more complex informal sector in the city of Palembang.

\section{Literature Review}

\section{Government Intervention}

Intervention is a series of forms of interference carried out by individuals/ groups/ institutions/ countries for other parties. Interventions can be negative or positive in form. In the studies of the informal sector, the interventions carried out by the government can be in negative forms such as evictions, illegal levies and so on. While, the positive interventions can be in the forms of giving business support, training, providing skills, relocation, and so forth. In the past, intervention was known as a term in politics in which certain countries interfere with other countries' affairs which are clearly not their business. In addition, there is also a definition of intervention which means an excessive interference in political, economic, social and cultural affairs ${ }^{1}$. Whereas, according to $K B B I$, intervention is interference in disputes between two parties (people, groups, countries, etc.) ${ }^{2}$.

Sumarni (2013) states that intervention is a form of government intervention in the management of economic activities. Interventions sometimes seem to be needed and sometimes feared. This depends on the nature of the intervention. If the intervention carried out is negative in nature, then either directly or indirectly it will be rejected by the party being intervened. But if the intervention is felt to have a positive impact, it will be accepted directly. Drajat (2009) states that intervention is a form of government attention to the agricultural sector by providing incentives and protection to the plantation subsector. So, based on some aformentioned definitions, interventioncan be interpreted as meddling with. In the context of this study the intervention was the government interference with female workers in the informal sector in Palembang City.

\section{The Dynamics of the Informal Sector}

So far there are two views related to the existence of the informal sector. Firstly, the informal sector is seen as a form of economic activity created by the failure of economic development. Secondly, the informal sector is a rational choice created by the high burden that must be incurred when becoming a formal sector (Williams \& Youssef, 2015). Both are correct and rational opinions to be used as the basis for the existence of the informal sector. In the current condition, the characteristics of the Indonesian workforce are mostly workers with inadequate levels of education and skills, so it is not surprising that the informal sector is an alternative to have as a job. 
The number of informal sector workers in Indonesia in August 2017 was 57.03 percent, while in South Sumatra Province the number of workers in the informal sector increased by 1.34 percent or 32.62 thousand (BPS, 2017).

The requirements for entering employment in the formal sector cannot be met by most job seekers in Indonesia. In addition, the number of employee recruitment in the formal sector employment is also limited and is held at certain times. This makes the opportunity to enter work in the formal sector increasingly difficult, consequently as a strategy for survival, job seekers choose to conduct informal activities while waiting for information and opportunities to get better jobs.

The role of the government in this condition is very necessary. The government should see the informal sector as one type of alternative employment in absorbing workforce. The government must not give up hands and seem to not pay attention to the informal sector workers. So far, the government's focus has been more on macroeconomic activities, but less attention is paid to microeconomic workers. This condition makes services and opportunities in the economic field are only enjoyed by certain groups of people or can be said to be more likely to be enjoyed by middle and upper economic groups. Whereas most of the population of Indonesia is middle to lower class and works in the informal sector.

The informal sector when introduced by Hart (1973) was described as an unregistered economic activity and outside government regulation. This concept tends to mean negative, so that the policy makers are more hostile to informal sector workers and they are considered as disturbing and damaging to the urban landscape. The informal sector is considered not to have contributed to the development because it is not taxed or giving other contributions. In the past, the informal sector was said to be lost in line with the progress of development in an area, but in fact the informal sector remained and increasingly varied, and many of the workers came from higher educational background (high school and above) (Sychareun et al., 2016) and (Barsoum, 2016)

\section{Research Methods}

This study uses a quantitative method with the design of survey method. Data collection is done by means of survey using questionnaires and documentation. The survey was conducted on 300 respondents who were female informal sector workers in Palembang City. The survey data are analyzed using analysis descriptive statistics frequencies and are presented in the form of discussion using tables, pie charts, and several references from relevant research or theory as findings' supports.

\section{Discussion}

\section{The Forms of Government Intervention for the Female Workers in the Informal Sector in Palembang City}

Interventions are all forms of attention, support and action from the government towards female workers in the informal sector. Interventions can be identified from several things such as; regulation, guidance, service and supervision. In this study the forms of government intervention will be seen from six aspects, namely: source of skills, provision of training, business capital, supervision, and access to information.

\section{Skills}

So far, informal workers have been synonymous with workers with low skills. Such condition makes it difficult for informal sector workers to develop and earn decent income. As it is traced further, it turns out that the majority of informal workers obtain skills as the results of their work experience. This means that their skills are acquired autonomously so that the ability standard also depends on how well the experience has been obtained. This fact shows that government intervention in terms of providing skills is still very lacking. This can be seen from the information provided by the women working in the informal sector in the city of Palembang.

According to the information provided by the female workers working in the informal sector, the source of their skills is self-taught skills. The percentage of this respondents reached 39 percent. Those who said that the skills were obtained from their family was 27 percent. So, in addition to being self-taught, the female workers in the informal sector in the city of Palembang also obtain their skills from the family. 
Figure 1. Sources of Skills

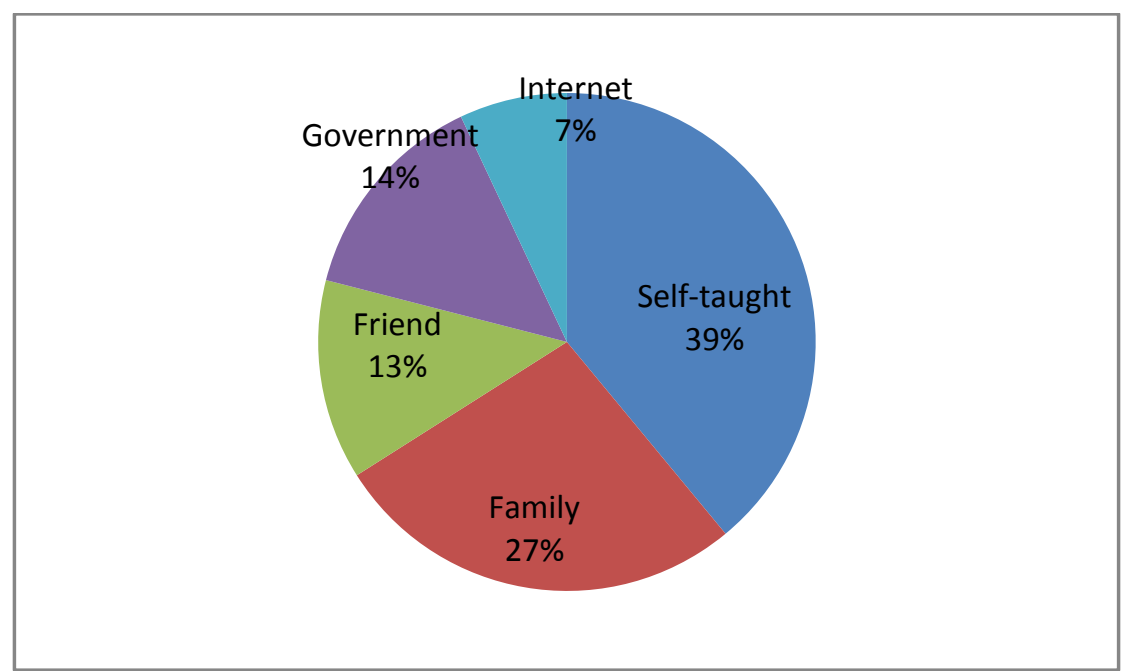

Source: Results of Field Data Processing (2018)

Based on Figure 1, the government intervention in providing skills to female workers in the informal sector in Palembang City is only 14 percent. The female workers in the informal sector obtain more skills from their families and friends. In addition, they also use internet media as a source to acquire skills. This finding shows that the government has provided an intervention effort in the form of providing skills for the female workers in the informal sector in Palembang City. Although the percentage is still relatively small, this effort has shown that the government does not have uncaring attitude in addressing the problems of the workforce in the informal sector.

This effort is expected to continue and develop, so that the assumption that has been stated so far that the informal sector is marginalized and discarded can begin to shift towards acceptance. The acceptance does not mean supporting informal activities but rather acceptance that aims to provide trust and opportunities to the informal sector to grow and develop into a formal sector that has the potential and increases income and creates new jobs.

\section{Training}

Training is an activity aimed at improving skills. The results of the study by Armansyah and Kiki Aryaningrum, 2017, revealed that the female workers in the informal sector claimed to have skills but could not use these skills to work due to limited capital. The female workers in the informal sector said that they obtain skills as the results of self-taught skills or from families. Only a few of the female workers in the informal sector have attended training held by the government. This condition also occurs to the female workers in the informal sector in Palembang in which 88 percent of the female workers in the informal sector say that there is no training from the government.

Figure 2.The Percentage of Female Workers in the Informal Sector Who Have Attended Training Provided by the Government

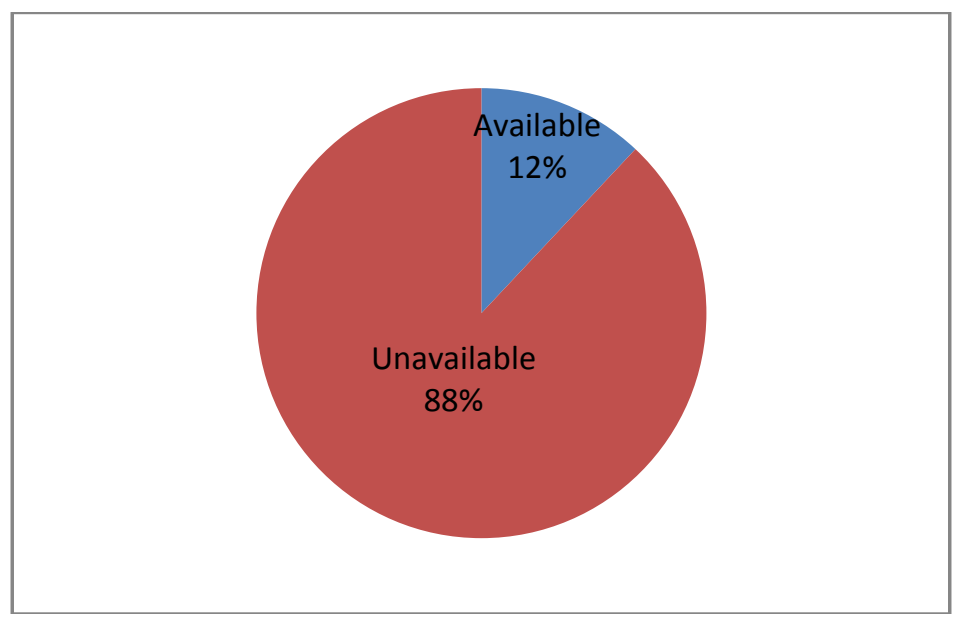

Source: Results of Field Data Management (2018) 
Based on Figure 2 above, there is only 12 percent of women in the informal sector who have received or participated in training provided by the government. This finding is similar to the findings of the study conducted by Armansyah and Kiki Aryaningrum (2017) which says that most women in the informal sector had never attended training. The reason is the limited information they obtain. In addition, the government is also not intensive in conducting socialization about the training programs it provides. The lack of training activities that have been attended by women in the informal sector will indirectly have an impact on the low skills possessed by the female workers in the informal sector. Even though skills are needed so that workers can have motivation to improve their business for the better. However, as previously explained in the skills section, this finding has shown that there is an attempt by the government to provide intervention in the form of training for female workers in the informal sector. This effort must be welcomed because it is the beginning of the development pattern which is based on the lower middle class.

Government intervention in an effort to improve skills through training needs to be appreciated. Because, for female workers in the informal sector who have passed school age or are unable to go to school, training is the solution. However, training should be held continuously and mentoring and evaluation should be carried out. It should also be directed to form communities so that independently the informal sector workers can have a place to share experiences and share information. This can also facilitate the government or the private sector in an effort to provide assistance and evaluation of informal sector workers. In addition, the existence of a community of informal sector workers can be well registered and will facilitate the government to provide information or assistance.

\section{Venture capital}

The venture capital referred to in this study is related to assistance in money, training / skills, and business tools. The data show that 81 percent of the female workers in the informal sector have never received capital assistance of any kind.

\section{Figure 3. The Percentage of Female Workers in the Informal Sector Who Have Ever Received} Any Capital Assistance

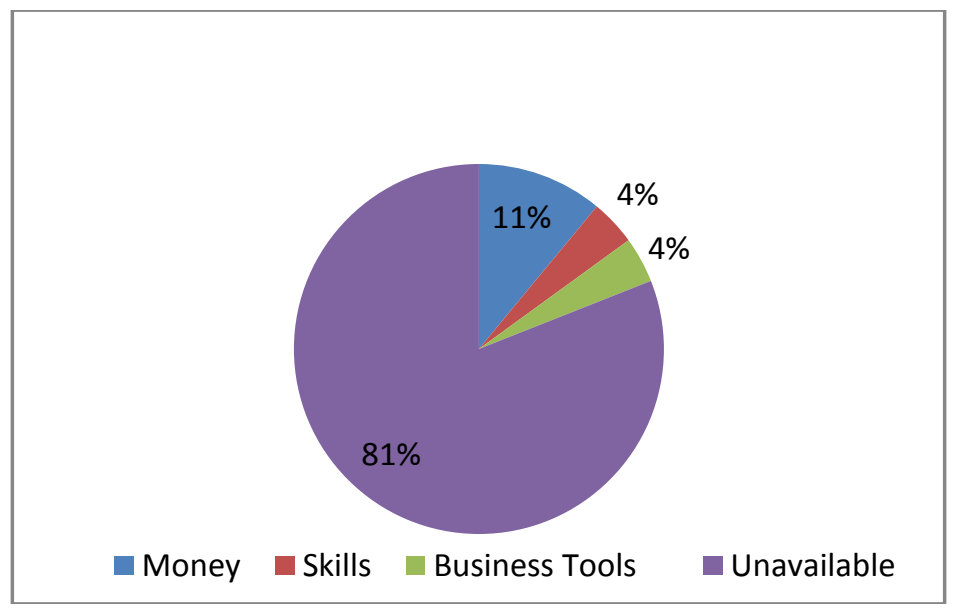

Source: Results of Field Data Management (2018)

The lack of this assistance is certainly has become a very serious obstacle to the development of the informal sector. Limited income, rising prices of basic commodities have increasingly made it difficult for the informal sector workers. There is no other way, assistance must be given to informal sector workers. The goal is to motivate and reward their efforts, not to maintain informal jobs but rather to support workers so they can try to improve their business, which will be expected to become formal. It is indeed not easy, but the government can try to form pilot groups, for example one $R T$, one business group, which will later be managed by several representatives of the population. They are given assistance, training, assistance, supervision, evaluation. This program aims to empower informal sector workers. They can build a business that aims to meet the basic needs of the surrounding population. If it has developed, the business can receive workers from the surrounding environment.

The aforementioned patterns can be an alternative that needs to be tested to start an economic development plan sourced from below. Most residents find it difficult to obtain assistance and attention from the government, so the work they do is only minimal, there is no quality standard, and good management of targets. This makes informal sector workers trapped in a never-breaking circle of poverty. Therefore, it is wise for the government to start efforts to 
empower the informal sector workers. Empowerment can be done in the potential informal sectors. Of course the potential criteria must have clear indicators or measurement tools.

To obtain these indicators the government can collaborate with universities or research institutions to conduct surveys and mapping of informal sector activities. Based on the results of the survey and mapping, the potential informal sectors can be identified which can then be given empowerment programs, such as; socialization, capital assistance, training, mentoring, marketing, evaluation and feedback.

Although the majority of the female workers in the informal sector stated that they had never obtained business capital from the government, the government had shown forms of intervention such as providing financial assistance, providing training / skills, and business tools. Although the percentage of those who have received the assistance is still very small, it is hoped that government intervention in the form of providing business capital can continue, so that more and more informal workers will receive business capital assistance. The hope is that this assistance can encourage the informal sector workers to work better so they can improve their business better and progressively.

\section{Supervision}

Intervention in the form of supervision is very necessary. The supervision here does not mean that the government always spies on informal sector workers. However, what is meant by supervision here is the government's efforts in providing assistance or monitoring evaluations of informal sector workers. This supervision is a continuation of the government intervention efforts that have been carried out such as providing business capital and skills. The aim is to see the extent to which the intervention that has been carried out successfully supports the business activities of informal sector workers.

The supervision is not only for certain groups, not only for political elites, entrepreneurs, and officials, but supervision is also needed by the layers of society who live in poverty. The supervision is not aimed at dictating or looking for mistakes, but aims to provide care and attention to the small people, and to show that the government exists for them. The research findings show that government intervention in the form of supervision is still very lacking. It is indicated by 87.3 percent of female workers in the informal sector who said that there was no supervision from the government.

Figure 4. The Percentage of Supervision Conducted by the Government towards Female Workers in the Informal Sector in Palembang City

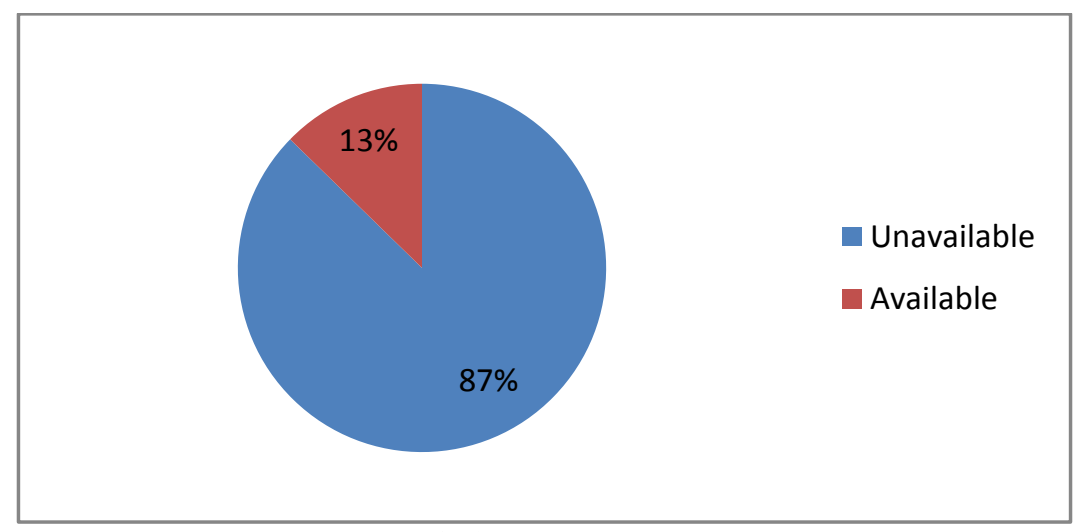

Source: Results of Field Data Management (2018)

This situation shows that there is a lack of government presence in the midst of communities of small people. The government seems to be giving up hands, leaving the situation of those who work in the informal sector as it is. Only a small proportion of female workers in the informal sector who have ever felt the presence of the government overseeing the activities they do. The supervision is very important to know more deeply about what is needed by small communities. The government must hear more voices from female workers in the informal sector, so that later they can provide solutions to the problems they face.

Never let the government officials come to the small community only for campaign purposes and give election promises. The poor people are not an object that deserves to be lied to as a target of lies and fulfills the appetite for votes. They need the government to really be there to help solve the economic problems of the small community. The government can delegate this supervisory task to the parties involved or cooperate with various institutions both government and private. Government programs such as PNPM, PAMSIMAS, KOTAKU, PKH which aim to manage the lives of the poor, such as informal sector workers, must be intensified. 
The government can seek a special empowerment program for informal sector workers considering that their access to banks and official government institutions is very low. For this reason, with the informal sector empowerment program the government can provide access to the informal sector workers to overcome various obstacles they have faced so far.

\section{Information}

The form of government intervention which is not less in importance is the provision of access to information. The lower class community has had difficulty getting information related to the policies or programs that overshadow them. As a result, informal sector workers are confined to a cycle of poverty because they do not have support to develop. The findings of this study indicate that 60 percent of the female workers in the informal sector in the city of Palembang stated that they did not know about information such as business assistance, training and so on.

\section{Figure 5. Information Sources of Female Workers in the Informal Sector in Palembang City}

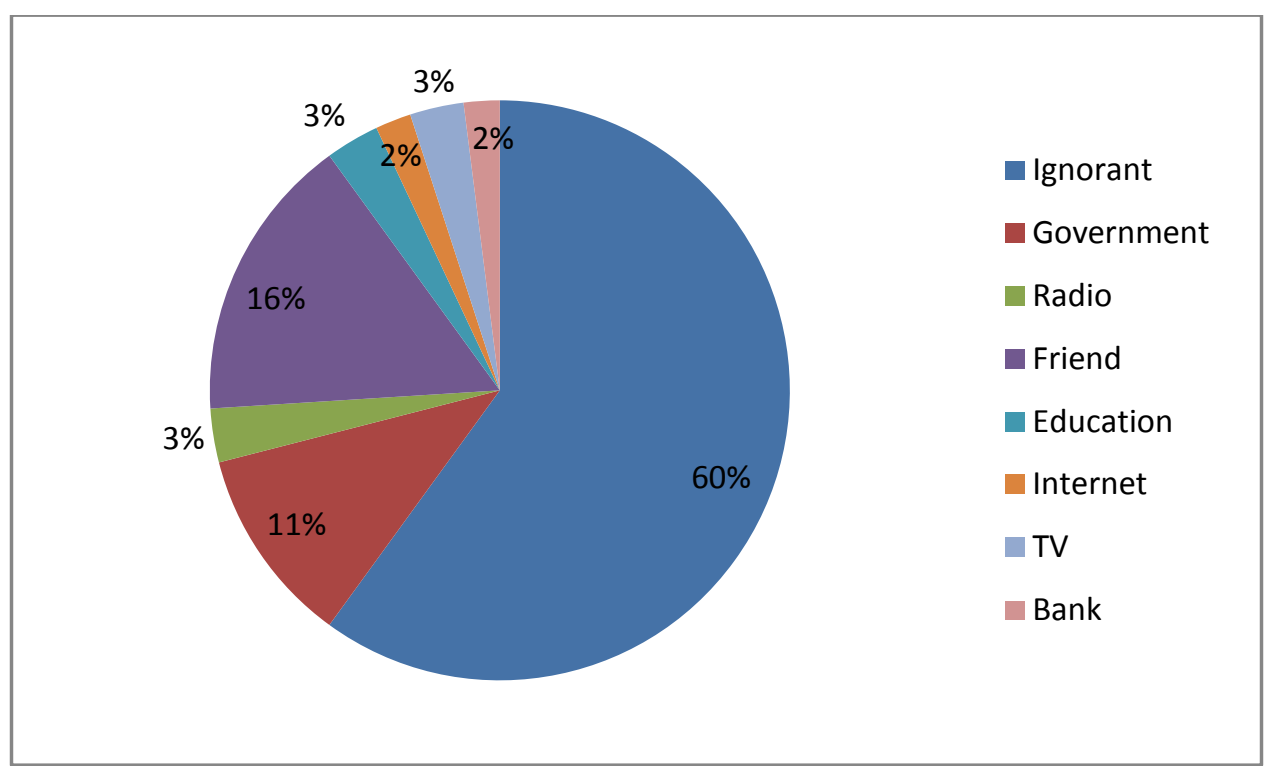

Source: Results of Field Data Management (2018)

Based on the data of Figure 5, the government intervention in the form of providing information is only 11 percent. While other sources of information are radio, friends, education, internet, television and even the bank. Even though it is only 11 percent, the figure has shown considerable effort from the government to provide information for female workers in the informal sector in the city of Palembang. It is undeniable that the female workers in the informal sector have many limitations including in terms of access to information. Where as information is still very important for them as a way to obtain knowledge or information about training and business assistance.

Therefore, the role of various parties in delivering information in an open and transparent manner is very necessary. There must not be any information cover up that make the lower class community difficult in accessing the information and ultimately they will not be involved in the activities held.

\section{Closing}

\section{Conclusion}

Although the informal sector has been identical with the jobs that are not registered and outside government regulations. But the fact in the field, the government has carried out a series of forms of intervention for informal sector workers, especially female workers in the informal sector in Palembang. The intervention is in the form of provision of skills, training, business capital, supervision and access to information. Although the forms of intervention are still very low, it needs to be appreciated, because previously the government attention to the informal sector was lacking. A small number of female workers in the informal sector in the city of Palembang have become trainees held by the government. Thus, it is expected that there will be increased skills of the female workers in the informal sector in the city of Palembang.

The thing that needs to be considered is the continuity of the intervention carried out by the government. For example, the provision of training and business capital needs to be followed by supervision and mentoring. So far, the female workers in the informal sector have stated that the government supervision is very low. After being given training and assistance to their businesses, they are confusedas to what activities to carry out next. 
Information access is also an obstacle for the female workers in the informal sector. So far, they do not receive much information about activities or programs that support the efforts they do.

\section{Suggestion}

Practically, the advice proposed by the author is directed to the government or private parties who care about the existence of the informal sector workers. Providing training and assistance is important for the informal sector workers, but it must be accompanied by a sustainability program and supervision or assistance. The informal sector workers can be facilitated to make communities as a forum for information sharing. In addition, the community can be a tool to record informal sector workers as well as a tool for the government to empower the informal sector. The recommendation for the future researchers interested in the existence of the informal sector is to conduct a research related to communication approaches that can be carried out based on local culture, so that it will be easier to empower the informal sector.

\section{References}

Ahdiah, O. I. (2013). Peran-peran perempuan dalam masyarakat (Women's roles in society). Jurnal Academica Fisip Untad, 5(2), 1085-1092.

Aparcana, S. (2017). Approaches to formalization of the informal waste sector into municipal solid waste management systems in low- and middle-income countries: Review of barriers and success factors. Waste Management, 61, 593-607. https://doi.org/10.1016/j.wasman.2016.12.028.

Armansyah; Kiki Aryaningrum. (2017). Analisis Karakteristik Demografi Pekerja Wanita Sektor Informal pada Era Masyarakat Ekonomi ASEAN di Kota Palembang (Analysis of Demographic Characteristics of Female Workers in the Informal Sector in the Era of the ASEAN Economic Community in Palembang City). Populasi, 25(1), 52-63. Retrieved from https://jurnal.ugm.ac.id/populasi/article/view/32415/19530.

Aswiyati, I. (2016). Peran Wanita Dalam Menunjang Perekonomian Kecamatan Kalawat (The Role of Women in Supporting the Economy of the Subdistrict of Kalawat). Jurnal Holistik, IX(17), 1-18.

Barsoum, G. (2016). "Job opportunities for the youth": Competing and overlapping discourses on youth unemployment and work informality in Egypt. Current Sociology, 64(3), 430-446. https://doi.org/10.1177/0011392115593614.

Drajat, Bambang. 2009. Dampak Intervensi Pemerintah Terhadap Kinerja Ekonomi Komoditas Perkebunan Utama pada Berbagai Rezim Nilai Tukar Rupiah 1979-2005 (Impact of the Government Intervention on Economic Performance of Major Plantation Commodities in Various Regimes ofRupiah's Exchange Rate of 1979-2005).Jurnal Agro Ekonomi Vol. 27, No. 1, May 2009: 61-80.

https://www.researchgate.net/publication/313932716_Dampak_Intervensi_Pemerintah_terhadap_Kinerja_Eko nomi_Komoditas_Perkebunan_Utama_pada_Berbagai_Rezim_Nilai_Tukar_Rupiah_1979-2005. Diakses 20 Januari 2019, Pukul 09:22 WIB.

Hart, K. (1973). Informal Income Opportunities and Urban Employment in Ghana. Source: The Journal of Modern African Studies, 11(1), 61-89. Retrieved from http://www.jstor.org/stable/159873.

Maryam Masood and Claire Y Barlow. (2013). Framework for integration of informal waste management sector with the formal sector in Pakistan. Waste Management \& Research, 31(10), 93-105. https://doi.org/10.1177/0734242X13499811.

Ramdan, I. M. (2012). Memperbaiki Kondisi Kesehatan dan Keselamatan Kerja Sektor Informal Melalui Program Corporate Social Responsibility Perusahaan (Improving the Occupational Health and Safety Conditions of the Informal Sector Through the Company's Corporate Social Responsibility Program). Jurnal Manajemen Pelayanan Kesehatan, 15(1). Retrieved from https://journal.ugm.ac.id/jmpk/article/viewFile/2505/2241.

Ritonga, T., \& Sari, R. L. (2015). Tingkat Kemampuan Pengusaha Sektor Informal dalam Mengakses Lembaga Perbankan di Kota Medan (Level of Ability of the Entrepreneurs of the Informal Sector in Accessing Banking Institutions in Medan City). Ekonomi Dan Keuangan, 2(12). Retrieved from https://jurnal.usu.ac.id/index.php/edk/article/view/11724/5095.

Soebyakto, B. B., \& Armansyah. (2016). Migrant Women Working at Informal Sectors : Empirical Study in Kuto Batu Village, Ilir Timur Ii Palembang City. International Journal of Humanities and Social Science, 6(4), 125-137.

Sugiyono. (2016). Metode Penelitian Kombinasi (Mixed Research Methods). (E. Sutopo, Ed.) (8th ed.). Bandung: Alfabeta. 
Sumarni. 2013. Intervensi Pemerintah: Antara Kebutuhan dan Penolakan di Bidang Ekonomi (Government Intervention: Between Needs and Refusals in the Field of Economy). Jurnal of Economic and Economic Education Vol. 1, No. 2 (183-194). https://media.neliti.com/media/publications/55621-ID-intervensipemerintah-antara-kebutuhan-d.pdf. Diakses 20 Januari 2019, Pukul 09:14 WIB.

Sychareun, V., Vongxay, V., Thammavongsa, V., Thongmyxay, S., Phummavongsa, P., \& Durham, J. (2016). Informal Workers and Access to Healthcare: A Qualitative Study of Facilitators and Barriers to Accessing Healthcare for Beer Promoters in The Lao People's Democratic Republic. International Journal for Equity in Health. https://doi.org/10.1186/s12939-016-0352-6.

Williams, C. C., \& Youssef, Y. (2015). Theorising Entrepreneurship in the Informal Sector in Urban Brazil: A Product of Exit or Exclusion? The Journal of Entrepreneurship, 24(2), 148-168. https://doi.org/10.1177/0971355715586897. 